\title{
Üniversite Binalarının Enerji Performans Değerlendirmesi: MCBÜ Köprübaşı Meslek Yüksekokulu Örneği
}

\author{
Ali Murat Ateş ${ }^{1 *}$, Özer Kestane², Koray Ülgen ${ }^{3}$ \\ ÖZ
}

Enerjide dışa bağımlılığın giderek arttığı ülkemizde en yoğun tüketim bina sektöründe olmaktadır. Bu sebeple binalarda enerji verimliliğini artıracak çözümlerin bir an önce uygulamaya geçmesi gerekmektedir. $\mathrm{Bu}$ amaç doğrultusunda oluşturulan bu çalışma kapsamında, Manisa Celal Bayar Üniversitesi bünyesinde hizmet veren Köprübaşı Meslek Yüksekokul binası irdelenerek enerji tasarruf performansı araştırılmış̧ır. Binanın mevcut durumunun davranışını belirlemek amacıyla yıl boyunca ölçümler yapılarak enerji kullanım düzeyi belirlenmiştir. Daha sonra önerilen iyileştirmeler sonucunda nasıl bir enerji tasarrufu sağlayacağını belirlemek amacıyla, bilgisayar tabanlı enerji modellemesi yapılmıştır. Simülasyon sonucunda elde edilen verilerden yola çıkarak, binanın enerji tasarruf potansiyeli ve iyileştirme sonucunda nasıl bir davranış göstereceği hesaplanmıştır. Hem ölçüm verilerinden hem de modellemeden elde edilen veriler doğrultusunda, mevcut bina y1llık bazda, $90,40 \mathrm{kWh} / \mathrm{m}^{2}$ yll enerji tüketirken, önerilen iyileştirmeler sonucunda $55,54 \mathrm{kWh} / \mathrm{m}^{2} \mathrm{y} 1$ enerji tüketir hale gelmiştir. Yani, yaklaşı $\% 40$ oranında enerji tasarrufu sağlama potansiyeli olduğu belirlenmiştir. Binanın mevcut durumdaki kullanım düzeyine göre sera gazı emisyonu $74,90 \mathrm{kgCO} / 2 \mathrm{~m}^{2} \mathrm{y}$ ll değerinde iken, önerilen iyileştirmeler ve bina çatısında hâlihazırda mevcut olan FV-GES'in desteğiyle bu değer $12,61 \mathrm{kgCO} / \mathrm{m}^{2} \mathrm{yl}$ değerine kadar düşeceği hesaplanmıştır.

Anahtar Kelimeler: Enerji analizi, Bina enerji modellemesi, Performans değerlendirmesi, Enerji yoğunluğu yaklaşımı

\section{Energy Performance Evaluation of University Buildings: MCBU Köprübaşı Vocational School Example}

\begin{abstract}
In Turkey, where foreign dependency in energy is increasing, the most intensive consumption is in the building sector. For this reason, solutions that will increase energy efficiency in buildings should be implemented as soon as possible. Within the scope of this study, created for this purpose, the energy saving performance was investigated at the Köprübaşı Vocational School building serving within the Manisa Celal Bayar University. In order to determine the behaviour of the current state of the building, the level of energy use was determined by making measurements throughout the year. Then, computer-based energy modelling was carried out to determine how to save energy as a result of the proposed improvements. Based on the data obtained as a result of the simulation, the energy saving potential of the building and how it will behave as a result of the improvement have been calculated. In line with the data obtained from both measurement data and modelling, while the current building consumed $90.40 \mathrm{kWh} / \mathrm{m}^{2}$ year on an annual basis, it became $55.54 \mathrm{kWh} / \mathrm{m}^{2}$ year as a result of the proposed improvements. In other words, it has been determined that it has the potential to save energy approximately $40 \%$. While the greenhouse gas emission is $74.90 \mathrm{kgCO}_{2} / \mathrm{m}^{2}$ year according to the current usage level of the building, it has been calculated that this value will decrease to $12.61 \mathrm{kgCO} / \mathrm{m}^{2}$ year with the support of the proposed improvements and PV-SPP currently available on the building roof.
\end{abstract}

Keywords: Energy analysis, building energy modelling, performance evaluation, energy density approach

\footnotetext{
" Iletişim Yazarı

Geliş/Received

Kabul/Accepted

10.04 .2021

16.06.2021

1 Manisa Celal Bayar Üniversitesi, Eğitim Fakültesi, Bilgisayar ve Öğretim Tek. Eğitimi Böl., Demirci, Manisa, murat.ates@cbu.edu.tr, ORCID: 0000-0002-2815-1404

2 Dokuz Eylül Üniversitesi, İzmir Meslek Yüksekokulu, Bilgisayar Teknolojileri Bölümü, Buca, İzmir, ozer.kestane@deu.edu.tr, ORCID: 0000-0001-6092-2881
}

3 Ege Üniversitesi, Güneş Enerjisi Enstitüsü, Bornova, İzmir, koray.ulgen@ege.edu.tr, ORCID: 0000-0002-9560-1727 


\section{ENTENDED ABSTRACT}

Continuous increase in energy consumption and meeting this need with fossil fuels that increase carbon emissions takes us towards an unsustainable future. Today, it is observed that energy consumption is constantly increasing in the building sector.

In accordance with the laws and regulations enacted to reduce the energy consumption in buildings, improvement methods have been determined according to points of building energy consumption In Turkey. At the same time, the classification method for whole buildings according to energy consumption, environmental interaction and renewable energy usage level is defined. A notice was issued determining the implementation principles of "Energy studies in public institutions and Efficiency Increasing Project (EIP)” In 2011. In this context, all official institutions have been obliged to implement the notice.

Within the scope of this study, Köprübaş1 Vocational School building, whose construction was recently completed, was selected as the reference building. The building has been studied by measuring its energy consumption. Improvement scenarios were created based on the findings obtained. These scenarios,

Scenario 1: The insulation properties of opaque components were increased. The average heat transfer coefficient $\left(\mathrm{U}_{\text {avg }}\right)$ of the model building has been reduced from $0.89 \mathrm{~W} / \mathrm{m}^{2} \mathrm{~K}$ to $0.784 \mathrm{~W} /$ $\mathrm{m}^{2} \mathrm{~K}$. For this purpose, the insulation thickness on the walls of the model building was taken into account as $10 \mathrm{~cm}$.

Scenario 2: In addition to S1, the heat transfer coefficient of the transparent components has been reduced. The heat transfer coefficient $(\mathrm{Uw})$ of the windows of the model building has been accepted as $1.2 \mathrm{~W} / \mathrm{m}^{2} \mathrm{~K}$ instead of $2.4 \mathrm{~W} / \mathrm{m}^{2} \mathrm{~K}$.

Scenario 3: In addition to S2, the solar control and transparency rate has been reduced. The lighting system of the model building was designed by connected the daylight automation system.

Scenario 4: In addition to $S 3$, the existing air conditioning system has been changed.

The energy performance of Köprübaş1 Vocational School building can be easily improved in terms of air conditioning. Considering the capacity of the Photovoltaic Solar Power Plant installed on the roof of the building, it will be very useful to air-condition the building with a heat pump. In this case, a high rate of reduction in greenhouse gas emissions created by coal used for heating will be achieved.

When the scenarios proposed in the simulation were considered in terms of implementation, the energy density of the building would be reach approximately $55.54 \mathrm{kWh} / \mathrm{m}^{2}$ year from 90.4 $\mathrm{kWh} / \mathrm{m}^{2}$ year, which would move the building to a higher class in terms of energy efficiency.

The annual emission value per usage area will decrease from $74.90 \mathrm{kgCO}_{2} / \mathrm{m}^{2}$ year in total to $12.61 \mathrm{kgCO}_{2} / \mathrm{m}^{2}$ year because of the improvements in the building, which has a very high emission in terms of greenhouse gases. This result would make the building environment friendly.

As a result, it has been determined that the Köprübaş1 Vocational School building has a significant energy saving potential, and the energy consumption, energy costs and $\mathrm{CO}_{2}$ emission amounts of the building can be reduced by using renewable energy technologies. 


\section{GİRIŞ}

Enerji ihtiyacının sürekli artması ve bu ihtiyacın karbon emisyonunu artıran fosil yakıtlarla karşılanması bizi sürdürülemez bir geleceğe doğru götürmektedir. Bir yandan artan enerji tüketimini karşılarken diğer yandan da karbon emisyonunu azaltmak amaciyla, yenilenebilir enerji santrallerinin enerji üretimindeki payı giderek artmaktadır. Ancak rüzgar türbinlerinin sürekli bakım ve onarım ihtiyacı olması [1] nedeniyle güneş, biyoyakıt, hidrotermal enerji gibi teknolojilerin potansiyeli artmaktadır [2]. Ayrıca kentlerde güneş enerjisinin etkin kullanılması için de çeşitli yöntemler bulunmaktadir [3].

Dünyadaki enerji talebinin 2010 ile 2040 yılları arasında, önceki 30 yıla göre, \%35 artacağı öngörülmüştür. Bu artışın en büyük payının yaşam alanları olduğu, ancak gerekli önlemler alınırsa $\% 30$ ile $\% 80$ arasında enerji talebinin azalma ihtimalinin olduğu ortaya konmuştur [4].

$\mathrm{Bu}$ nedenle, enerji açısından hem kendi kendine yetebilen hem de çevreye duyarlı enerji kullanımını desteklemek amacıyla, birçok ülkede olduğu gibi Türkiye'de de 2007 yılında "Enerji Verimliliği "Kanunu” çıkarılmıştır. Bu kanunun amacı; enerjinin etkin kullanılması, israfının önlenmesi, enerji maliyetlerinin ekonomi üzerindeki yükünün hafifletilmesi ve çevrenin korunması için enerji kaynaklarının ve enerjinin kullanımında verimliliğin artırılmasıdır [5].

Enerji Verimliliği Kanununun bina sektörüne uygulamasını sağlayacak olan ve 2008 yılında "Binalarda Enerji Performans Yönetmeliği" adıyla çıkarılan yönetmeliğe göre, binaların bütün enerji kullanımlarının ve karbon emisyonlarının değerlendirilmesi ve çevrenin korunması üzerine önlemler alınması zorunlu hale getirilmiştir [6].

$\mathrm{Bu}$ yönetmelik kapsamında kullanım amacına göre binalarda enerji tüketiminin azaltılması amaçlanırken, özellikle de ülkelerin en eğitimli kesimlerinin bulunduğu üniversitelerin kendi binalarındaki enerji tüketimini iyi yönetmesi ve olabildiğince karbon emisyonunu azaltacak şekilde planlaması, temiz bir gelecek için topluma iyi örnek olmalarını sağlayacaktır. Ancak, yüksek öğretim binalarının enerji yönetimi metodolojisi konusunda bir boşluk bulunduğu ve bu durumun üniversite binalarındaki enerji verimliliği konusunda bir engel oluşturduğu vurgulanmıştır [7].

Ulusal ve uluslararası literatürlerde mevcut olan birçok çalışmada belirtildiği gibi eğitim kurumlarında enerji verimliliğinin, kullanıcıların konforunun önüne geçmemesi gerektiği de özellikle vurgulanmıştır [8-12]. Özellikle bina içi termal konforun sağlanabilmesi için oluşturulan sistemlerin ve bunların enerji tüketimi ile sağladığ konfor düzeylerinin belirlenmesi üzerine gerçekleştirilen çalışmalara göre, Assiut Üniversitesi Mühendislik Fakültesi konferans salonunda, oluşturulan çözümün düzeyini belirlemek için 331 katılımcı üzerinde bir anket çalışması yapılmış ve anket sonucuna göre iç mekan soğutma ve enerji verimliliği üzerine değerlendirmeler ya- 
pılmıştır [10]. Bir başka çalışmada İran'ın üç kentinde, dokuz devlet okulunun bina enerji performansı simüle edilmiştir. Pencerelerde çıkıntılar eklemek haricinde, tüm senaryolarda 1sıtma için doğal gaz kullanımının azaltıldığ 1 sonucu elde edilmiştir. Yapılan değerlendirmeler doğal gaz kullanımının Ilam'da \%79, Yazd'da \%74 ve Tebriz'de \%63 oranında önemli bir düşüş olacağını göstermektedir [13]. Sheffield Üniversitesindeki iki eğitim binasının enerji, termal konfor ve çevre stratejisi arasındaki ilişkilerin karşılaştırılması yapılmıştır. Bu karşılaştırmaya göre tasarımcıların daha rahat, düşük enerjili çalışma alanları sunmak için aktif ve pasif tasarım ilkelerini nasıl kullanabileceği vurgulanmıştır. Çalışmada kişi başına düşen enerjinin tahmini ve değerlendirilmesinin enerji performansı ile konfor arasındaki ilişkide önemli bir rol oynayabileceği gösterilmiştir [14].

Kampüs binalarının enerji tüketimini ve yönetimi ile ilgili birçok uygulama mevcuttur. Bu uygulamaların genel yapısı bina talep yükleri, enerji kullanım düzeyleri ve enerji denetim modellerini içermektedir. Buna göre, Zagreb Üniversitesinde 23 fakülte binasının enerji denetimi ve enerji sertifikası sürecinin gelişimi sergilenmiştir. Çalışma sonuç olarak enerji tasarruflu iyileştirme önlemleri ve karlılık hesaplamaları önerisinde bulunmaktadır [15]. Norveç’te bir üniversite kampüs binasının talep yükü ve enerji kullanımının özelliklerini ortaya koyan bir metodoloji geliştirilmiştir. Çalışmada kampüsün elektrik, 1sıtma ve su kullanımının uzun vadeli ve gerçek zamanlı verileri analiz edilmiştir. Bu analize göre, işletme optimizasyonu potansiyeli yüksek olan binaları belirlemek için toplam kampüs enerji kullanımına bireysel tesadüfi katk1 küme analizi yöntemi kullanılmasının uygun olduğu tespit edilmiş, şehirlerin ve diğer kentsel enerji sistemlerinin enerji planlaması için bu yöntemin kullanılabileceği belirtilmiştir [16]. İngiltere'de 5 farklı yükseköğretim kurumunda 12 ay süren bir çalışmada binaların faaliyetleri, inşaat tarzları, enerji sistemleri ve işletim özellikleri değerlendirilmiştir. Karbon emisyonunu azaltmak için olası senaryolar belirlenerek en etkili müdahale ile yaşam döngüsü değerlendirmesine göre karbon emisyonunun \%20 -29 arasında, enerji tasarrufunun ise \%32-64 arasında azaltılacağı belirlenmiştir [17]. Başka bir çalışmada 1985 yılı öncesi inşa edilmiş, İngiliz ve Galler üniversite binaları için yaşam döngüsü karbon modelleri dikkate alınarak bir veritabanı oluşturulmuştur. $\mathrm{Bu}$ veritabanı enerji verileri kullanılarak kalibre edilmiş ve karbon azaltma müdahalelerini ve yeni inşa planlarını simüle etmek için kullanılmıştır. Yeni inşa edilecek binalar için ortalama yaşam döngüsü karbon tasarrufunun \%37-54 arasında değişeceği sonucunu elde etmişlerdir [18]. Stockholm'deki Albano üniversite kampüsünde gerçekleştirilen bir çalışmada, enerji sistemi tasarımına çok amaçlı bir optimizasyon yaklaşımı uygulanmıştır. Çalışmada, çevre, ekonomi ve ekserji odaklı senaryolar temelinde dört optimal çözüm önerilmiştir [19]. Kampüs binalarının toplam enerji tüketiminin kullanım noktalarına göre (1sıtma, soğutma, havalandırma, sıcak su eldesi, aydınlatma) analizi amaçlı birçok sistematik yaklaşım geliştirilmiş, enerji tüketiminin çevresel etkileri detaylı bir şekilde ortaya konulmuştur [20-28]. 
Ulusal düzeyde binalarda enerji tüketimi ve analizi ile ilgili gerçekleştirilen çalışmalar, kaynak tüketimi, sistem kullanımı ve performans değerlendirilmesi açısından detaylandırılmıştır. Bu kapsamda yapılan çalışmalarda enerji ve ekserji analizi, performans değerlendirmesi temel odak noktasını oluşturmaktadır [29-32].

Ülkemizde Ege Üniversitesi UBE binasında [33], İzmir Yüksek Teknoloji Enstitüsü Mimarlık Fakültesi'nde [34], Karamanoğlu Mehmet Bey Üniversitesi'nde [35], MCBÜ Köprübaşı Meslek Yüksekokulu'nda [36] binaların enerji analizine yönelik çalışmalar dikkat çekmektedir. Bu çalışmalar kapsamında dikkate alınan binalar enerji kullanım düzeylerine, enerji tüketim noktalarına, çevresel etkileşime, aktif ve pasif iyileştirme alternatiflerine göre değerlendirilmiştir.

Bu çalışma kapsamında Manisa Celal Bayar Üniversitesi Köprübaşı Meslek Yüksekokulu binası örnek olarak alınmış, yıllık enerji tüketim alışkanlığı belirlenmiş, BEP yönetmeliğine göre standart sınıfı tayin edilmiş ve enerji tüketimini iyileştirmek amac1yla alternatif önerilerinde bulunulmuştur.

\section{2. ÇALIŞMA ALANI}

\subsection{Coğrafi Konumu ve Bina Özellikleri}

Köprübaşı MYO binası ile ilgili konum, yönelim ve çevresel bilgiler Tablo 1'de verildiği gibidir [36].

Manisa Celal Bayar Üniversitesi Köprübaşı Meslek Yüksekokulu binası, 2 farklı kütleden oluşmaktadır. Binanın toplam oturma alanı $1.486 \mathrm{~m}^{2}$ olup, iki kattan oluşmaktadır. Binanın toplam kullanım alanı $2.972 \mathrm{~m}^{2}$, brüt hacmi $11.294 \mathrm{~m}^{3}$ 'tür. Binanın toplam yüzey alanı $1.647,38 \mathrm{~m}^{2}$ olup bunun $473,81 \mathrm{~m}^{2}$ 'si cam yüzey alanı olarak kullanılmaktadır. Yani, binanın yüzey alanın \%29’u pencere olarak oluşturulmuştur (Şekil 1).

Binanın 1sıtma enerjisi ihtiyac1 $350.000 \mathrm{kcal} / \mathrm{h}$ (407 kW) gücünde kömür yakıtlı bir yakma sisteminden karşılanmaktadır. Binanın soğutma enerjisi ihtiyacı ise, $108 \mathrm{~kW}$ toplam kurulu gücüne sahip 18 adet duvar tipi klima sistemi ile karşılanmaktadır.

Tablo 1. Köprübaşı MYO Binasının Bilgileri

\begin{tabular}{|l|l|l|}
\hline \multirow{2}{*}{ Konum } & Enlem & $38,457381^{\circ}$ \\
\cline { 2 - 3 } & Boylam & $27,214422^{\circ}$ \\
\cline { 2 - 3 } & Rakım & $250 \mathrm{~m}$ \\
\hline \multirow{2}{*}{ Yönelim } & $\begin{array}{l}\text { Ana bina Kuzey-Güney doğrultusunda, Güneyden Doğuya doğru } 20^{\circ} \text { açı ile. } \\
\text { İdari bina Doğu-Batı doğrultusunda. Doğudan Kuzeye doğru } 20^{\circ} \text { açı ile. } \\
\text { (Azimut -20 }\end{array}$ \\
\hline Çevresel etki & Dört tarafı açık, yakın yapıların ve ağaçların gölge etkisi yoktur. \\
\hline
\end{tabular}




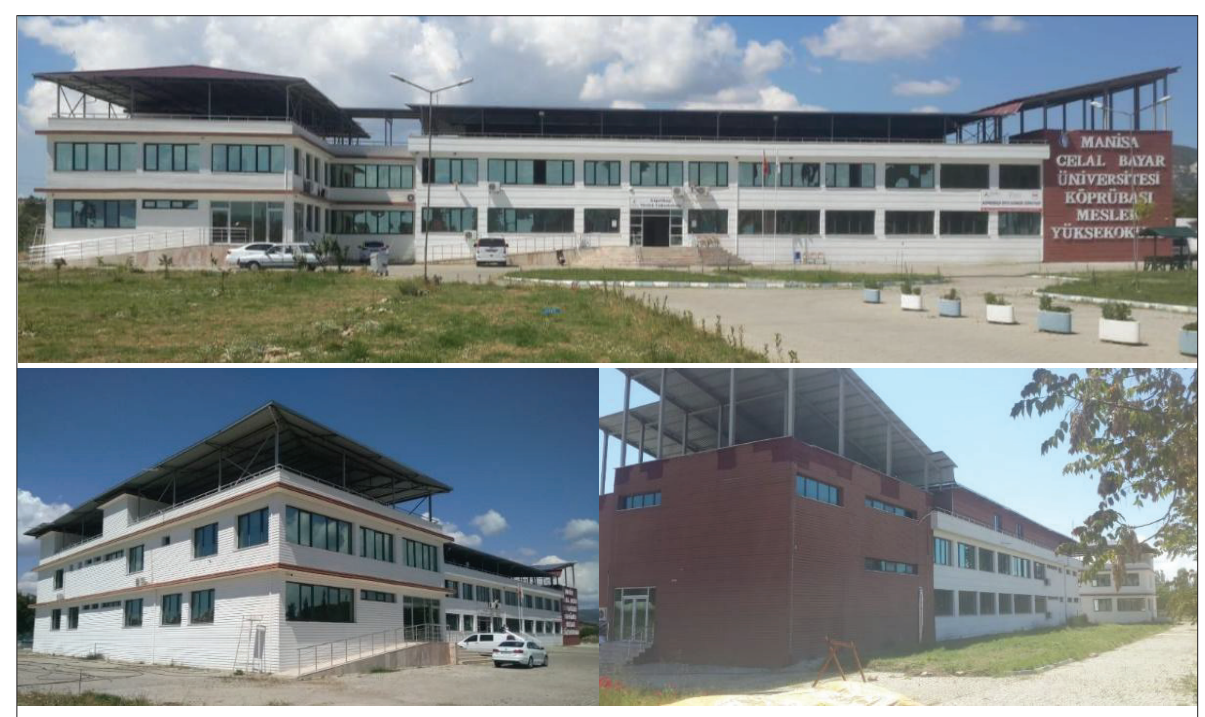

Şekil 1. Köprübaşı Meslek Yüksekokulu Binasının Cephe Görünüşleri

Bina çatısına 30kWp gücünde bir Fotovoltaik (FV) Güneş Enerji Santrali (GES) kurulmuş ve 2018 yılı haziran ayında yasal süreçleri tamamlanarak devreye alınmıştır.

Köprübaşı Meslek Yüksekokulu binası 2016 yılı içerisinde bitirilmiş olup, binanın mevcut durumunda yapı elemanlarının toplam ısı geçiş katsayıları ve TS 825'in öngördüğü değerler [37] Tablo 2'de verildiği gibidir. Binanın cephesinde opak yüzeylerde 4 cm kalınlığında ısı yalıtım levhası kullanılarak TS 825 standardına göre mantolama uygulaması gerçekleştirilmiştir. Aynı zamanda binanın saydam yüzeyleri ise TS 825 standardına uygun olan çift camlı PVC doğrama sistemi ile kaplanmıştır.

Tablo 2. Binanın Yapı Elemanlarının Toplam Isı Geçiş Katsayıları ve Özgül Isı Kayıpları

\begin{tabular}{|l|c|c|c|c|}
\hline \multirow{2}{*}{ Yapı Elemanı Tipi } & \multicolumn{2}{|c|}{$\mathrm{U}\left(\mathrm{W} / \mathrm{m}^{2} \mathrm{~K}\right)$} & \multirow{2}{*}{ Alan $\left(\mathrm{m}^{2}\right)$} & \multirow{2}{*}{ UA (W/K) } \\
\cline { 2 - 3 } & Mevcut & TS 825 & & \\
\hline Duvar & 0,667 & 0,600 & 767,51 & 511,67 \\
\hline Betonarme yapı elemanları & 0,833 & 0,600 & 381,63 & 318,03 \\
\hline Tavan & 3,191 & 0,400 & $1.486,00$ & $4.741,23$ \\
\hline Taban & 1,044 & 0,600 & $1.486,00$ & 775,89 \\
\hline Pencere & 2,400 & 2,400 & 473,81 & $1.137,14$ \\
\hline Kapı & 4,000 & - & 24,43 & 97,72 \\
\hline$H_{T}(W / K)$ & & & $7.581,68$ \\
\hline Havalandırma, $H_{v}(W / K)$ & & & $2.087,13$ \\
\hline$H(W / K)$ & & & $9.668,81$ \\
\hline
\end{tabular}




\section{2 İklimsel Veriler}

Manisa'nın Köprübaşı ilçesinde aylık ortalama yatay yüzeyde toplam güneş 1şınımı $\left(\mathrm{H}_{\mathrm{T}}\right)$, yatay yüzeyde direkt güneş 1 şınımı $\left(\mathrm{H}_{\mathrm{B}}\right)$, yatay yüzeyde yayılı güneş 1 şınımı $\left(H_{D}\right)$, ortam sıcaklığg $\left(T_{\text {amb }}\right)$, rüzgâr hızı $\left(V_{W}\right)$ ve bağıl nem $\left(R_{h}\right)$ değerleri Tablo 3 'te verilmiştir.

Tablo 3. Köprübaşı'nın Aylık Ortalama İklimsel Verileri

\begin{tabular}{|l|c|c|c|c|c|c|}
\hline Aylar & $\begin{array}{c}\mathbf{H}_{\mathrm{T}} \\
\left(\mathbf{W h} / \mathbf{m}^{2}\right)\end{array}$ & $\begin{array}{c}\mathbf{H}_{\mathrm{B}} \\
\left(\mathbf{W h} / \mathbf{m}^{2}\right)\end{array}$ & $\begin{array}{c}\mathbf{H}_{\mathrm{D}} \\
\left(\mathbf{W h} / \mathbf{m}^{2}\right)\end{array}$ & $\begin{array}{c}\mathbf{T}_{\text {amb }} \\
\left({ }^{\circ} \mathbf{C}\right)\end{array}$ & $\begin{array}{c}\mathbf{V}_{\mathbf{w}} \\
(\mathbf{m} / \mathbf{s})\end{array}$ & $\begin{array}{c}\mathbf{R}_{\mathrm{h}} \\
(\%)\end{array}$ \\
\hline Ocak & 63,15 & 23,08 & 40,21 & 3,13 & 3,72 & 88,45 \\
\hline Şubat & 131,91 & 77,60 & 54,34 & 4,77 & 3,40 & 79,19 \\
\hline Mart & 205,15 & 144,68 & 60,52 & 7,47 & 3,39 & 75,25 \\
\hline Nisan & 222,85 & 132,98 & 89,92 & 10,46 & 3,08 & 73,47 \\
\hline Mayıs & 265,66 & 161,98 & 103,73 & 17,01 & 2,71 & 65,23 \\
\hline Haziran & 289,93 & 205,96 & 84,00 & 22,37 & 3,20 & 59,66 \\
\hline Temmuz & 318,29 & 248,40 & 69,89 & 24,42 & 3,36 & 46,92 \\
\hline Ağustos & 295,52 & 231,11 & 64,41 & 26,09 & 3,99 & 42,49 \\
\hline Eylül & 230,93 & 169,10 & 61,84 & 21,85 & 3,20 & 46,02 \\
\hline Ekim & 165,94 & 115,95 & 50,08 & 17,63 & 2,56 & 54,72 \\
\hline Kasım & 104,08 & 62,56 & 41,61 & 12,64 & 2,68 & 65,81 \\
\hline Aralık & 81,76 & 46,28 & 35,57 & 5,44 & 3,11 & 75,74 \\
\hline Yıllık Ort. & 197,93 & 134,97 & 63,01 & 14,44 & 3,20 & 64,41 \\
\hline
\end{tabular}

2019 yılında, bölgedeki yatay yüzeydeki ışınımın aylık ortalaması 63,15 Wh/m² (Ocak) ile 318,29 Wh/m² (Temmuz) arasında değişmekle beraber yıllık ortalama 1şınım değeri 197,93 Wh/m² olarak gerçekleşmiştir. Aylık ortalamada en düşük ve en yüksek sıcaklıklar ile yıllık ortalama sıcaklık değeri de sırasıyla $3,13^{\circ} \mathrm{C}, 26,09^{\circ} \mathrm{C}$ ve $14,44^{\circ} \mathrm{C}$ olarak kayıt altına alınmıştır. Yıllık ortalama rüzgâr hızı $3,20 \mathrm{~m} / \mathrm{s}$ ve bağıl nem değeri de $\% 64,41$ 'dir.

\subsection{Enerji Ölçümleri}

Köprübaşı MYO binasının Binalarda Enerji Performans Yönetmeliğine göre öngörülen yıllık bazda enerji tüketimini belirlemek amacıyla, proje kapsamında bir ölçme sistemi tasarlanmıştır. Bu sistem elektriksel tüketimini ölçmek amacıyla 18 farklı noktanın tüketimini ölçmek için enerji analizörleri kullanılmıştır (Şekil 2). Her bir kanaldan, binadaki mevcut klimaların enerji tüketim düzeyleri ölçülmüştür. Cihazlar arasına RS-485 protokolünü kullanan kablolama yapılarak tüm noktalardaki tüketimler bir veri kaydedicide (bilgisayar) toplanmıştır. 


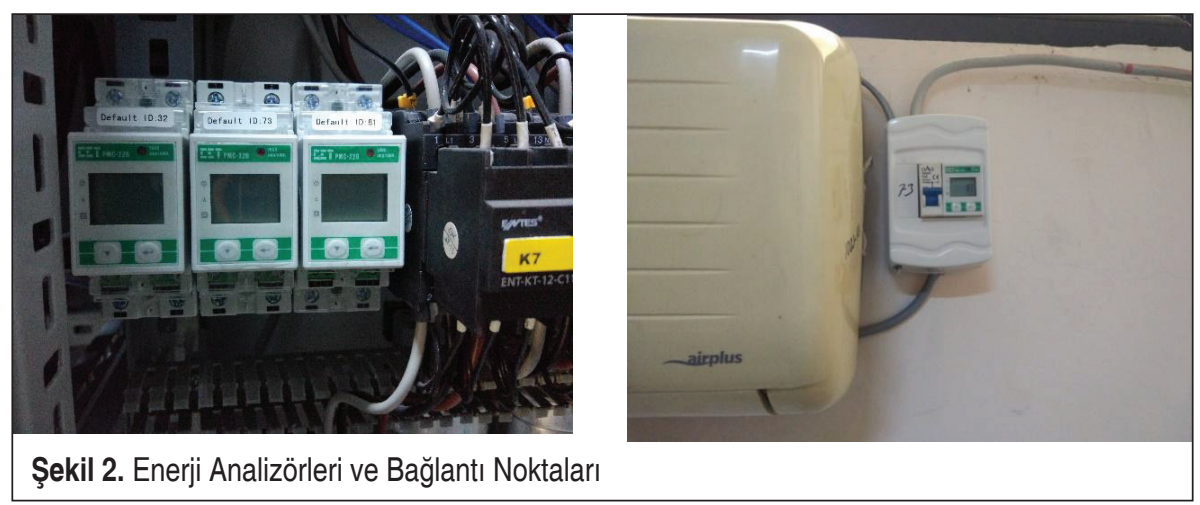

Ayrıca, sıcaklığın mekân içerisindeki dağılımını belirlemek amacıyla, bina modelinin geliştirilmesinde anahtar derecede önemli 20 mekânda düşey yönde sıcaklık dağılımını analiz etmek için, diz, göğüs ve baş hizasında ölçüm yapacak bir ölçme düzeneği geliştirilmiştir. Bunun için her biri sekiz kanallı olan nano Arduino'lar kullanılarak sistem oluşturulmuştur (Şekil 3).
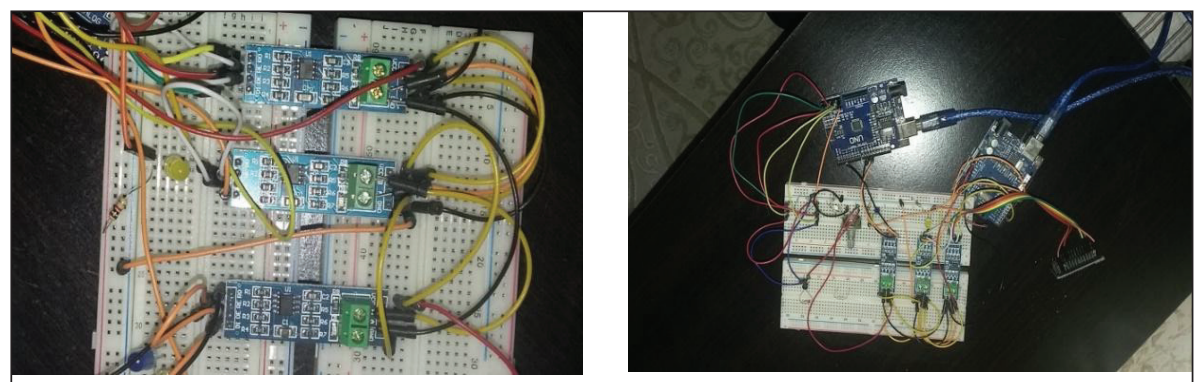

Şekil 3. Sıcaklık ve Aydınlık Düzeyi Ölçüm Sistemi

Aynı zamanda bu ölçüm sistemi, mekânları 1sıtmak için kullanılan radyatörlerin etkinliğini belirlemek amacıyla, radyatörün hem giriş hem de çıkış hattında sıcaklık ölçümü gerçekleştirilmiştir. Binanın ısıl performansının yanında aydınlatma sisteminin de analizini yapabilmek için, kapalı, yarı açık ve açık gökyüzü koşulları için, mekân içerisindeki aydınlık seviyeleri de kayıt altına alınmalıdır.

Bina içindeki ısıl dağılımı ve aydınlık seviyesini tespit etmek amacıyla 100 noktadan sıcaklık ve 20 noktadan aydınlık seviyesi ölçümü yapılabilen bir sistem tasarlanmıştır. Tasarlanan 1Sı ve aydınlık seviyesi ölçüm sistemine ait deney fotoğrafları ve kutuya yerleştirildikten sonraki hali Şekil 4'te verilmiştir. Her birinde 5 adet 1sı ve bir adet 1ş1k sensörü bulunan toplam 20 adet cihaz RS-485 protokolü üzerinden haberleşecek şekilde tasarlanmıştır.

Tüm ölçüm verilerini aynı bilgisayar üzerine toplamak için de bir yazılım geliştirilmiştir. Yazılımın ekran görüntüsü Şekil 5'te görüldüğü gibidir. Yazılım, istenilen 
periyotlarda, 1Sı ve aydınlık seviyesi ölçen modüllerdeki toplanan verileri RS-485 protokolü üzerinden alarak bilgisayarda MSSQL Server üzerinde oluşturulmuş olan veri tabanına depolamaktadır. Ölçüm periyotları, yazılım üzerinden, istenilen aralıkta ayarlanabilmekte olup buradaki sistemde 5 dakika olarak belirlenmiştir. Bu durumda binadaki istenen noktalardaki ısı ve aydınlık seviyesi bilgileri 5'er dakikalık ortalamalar şeklinde ölçülmüş ve bilgisayar sisteminde depolanmış olacaktır. Binadaki enerji analizörleri de 5 dakikalık ortalamalar şeklinde kayıt vermektedir.

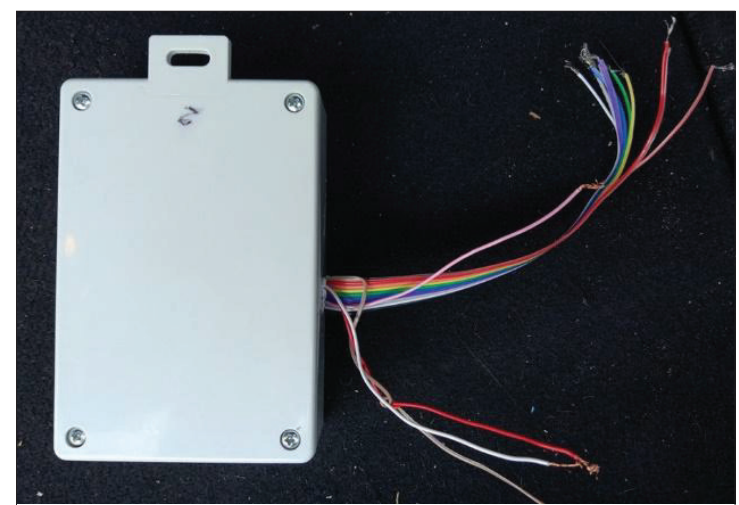

Şekil 4. Ölçüm Sisteminin Son Hali

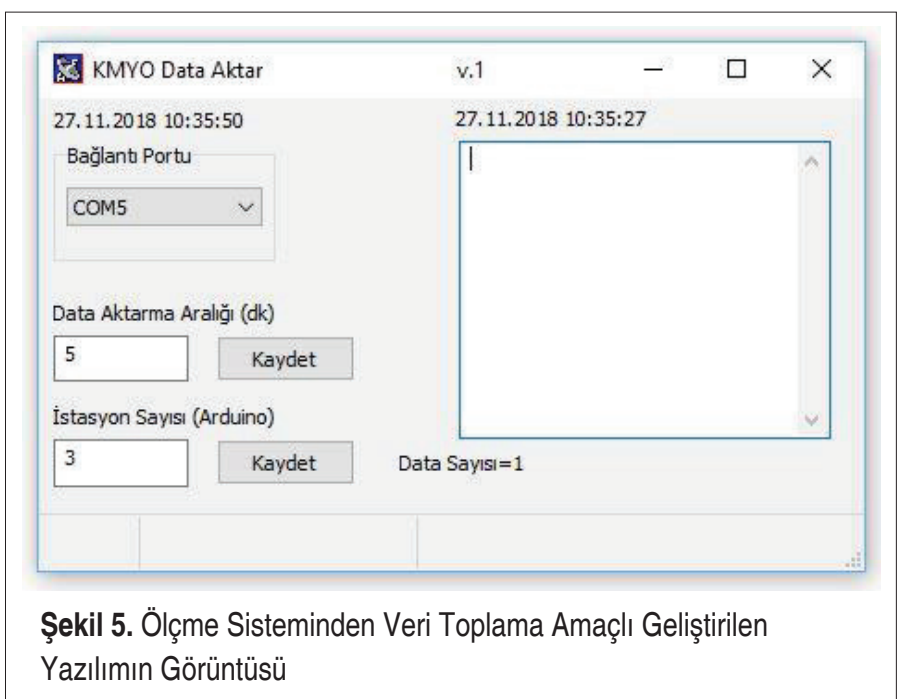

\subsection{Enerji Üretim ve Tüketim Değerleri}

Model binanın 2019 yılında kaydedilen ısıl ve elektrik enerjisi tüketimi ve çatıda bulunan $30 \mathrm{kWp}$ gücündeki çatı üstü PV sistemi tarafından üretilen elektrik enerjisi verileri Tablo 4'te verilmiştir. 
Tablo 4. Aylık Enerji Tüketim Değerleri

\begin{tabular}{|c|c|c|c|c|c|}
\hline \multirow{3}{*}{ Aylar } & \multicolumn{4}{|c|}{ Tüketim } & \multirow{3}{*}{$\begin{array}{c}\text { Üretim } \\
\text { Elektrik } \\
\text { (kWh) } \\
\end{array}$} \\
\hline & \multicolumn{2}{|c|}{ Kömür } & \multirow{2}{*}{$\begin{array}{c}\text { Elektrik } \\
\text { (kWh) } \\
\end{array}$} & \multirow{2}{*}{$\begin{array}{c}\text { Toplam } \\
\text { (kWh) }\end{array}$} & \\
\hline & (kg) & (kWh) & & & \\
\hline Ocak & 9.367 & 59.899 & 4.381 & 64.281 & 1.423 \\
\hline Şubat & 7.722 & 49.384 & 3.714 & 53.098 & 2.725 \\
\hline Mart & 5.197 & 33.236 & 2.864 & 36.100 & 4.323 \\
\hline Nisan & 2.555 & 16.336 & 2.500 & 18.836 & 4.247 \\
\hline Mayıs & 0 & 0 & 1.715 & 1.715 & 4.665 \\
\hline Haziran & 0 & 0 & 2.863 & 2.863 & 4.928 \\
\hline Temmuz & 0 & 0 & 2.374 & 2.374 & 5.685 \\
\hline Ağustos & 0 & 0 & 2.400 & 2.400 & 5.332 \\
\hline Eylül & 0 & 0 & 2.154 & 2.154 & 4.426 \\
\hline Ekim & 0 & 0 & 2.159 & 2.159 & 3.650 \\
\hline Kasım & 1.762 & 11.266 & 2.341 & 13.607 & 2.265 \\
\hline Aralık & 8.398 & 53.703 & 3.896 & 57.598 & 1.956 \\
\hline Toplam & 35.000 & 223.825 & 33.360 & 257.185 & 45.625 \\
\hline
\end{tabular}

Binada tüketilen elektrik enerjisinin aylık dağılımı Tablo 5’te verilmiştir.

Tablo 5. Elektrik Tüketiminin Dağıımı

\begin{tabular}{|l|c|c|c|c|}
\hline Aylar & $\begin{array}{c}\text { iklimlendirme } \\
\mathbf{( k W h )}\end{array}$ & $\begin{array}{c}\text { Aydınlatma } \\
\mathbf{( k W h )}\end{array}$ & $\begin{array}{c}\text { Diğer } \\
\mathbf{( k W h )}\end{array}$ & $\begin{array}{c}\text { Toplam } \\
\mathbf{( k W h )}\end{array}$ \\
\hline Ocak & 1.891 & 442 & 2.049 & 4.381 \\
\hline Şubat & 1.594 & 352 & 1.768 & 3.714 \\
\hline Mart & 917 & 321 & 1.627 & 2.864 \\
\hline Nisan & 866 & 245 & 1.389 & 2.500 \\
\hline Mayıs & 570 & 145 & 1.000 & 1.715 \\
\hline Haziran & 638 & 140 & 2.185 & 2.863 \\
\hline Temmuz & 765 & 2 & 1.606 & 2.374 \\
\hline Ağustos & 1.212 & 6 & 1.182 & 2.400 \\
\hline Eylül & 1.259 & 29 & 867 & 2.154 \\
\hline Ekim & 374 & 270 & 1.515 & 2.159 \\
\hline Kasım & 559 & 357 & 1.424 & 2.341 \\
\hline Aralık & 1.381 & 460 & 2.055 & 3.896 \\
\hline Toplam & 12.024 & 2.670 & 18.667 & 33.360 \\
\hline
\end{tabular}




\section{YÖNTEM}

Literatürde binaların ısıtma ve soğutma enerjisi ihtiyacını belirlemek için birçok yaklaşım mevcuttur. Bu yaklaşımlar, statik, yarı dinamik ve dinamik çözüm algoritmalarını dikkate almaktadır. Hesap kolaylığı açısından statik yaklaşım olarak ifade edilen, aylık ısıtma ve soğutma enerji ihtiyaçlarının belirlenmesi yöntemi bu çalışmada dikkate alınmıştır.

\subsection{Isıtma Enerjisi İhtiyacı}

Bir binanın aylık ısıtma enerjisi ihtiyacı, binanın 1sıtma yükü ile 1sı kazançları arasındaki fark olarak dikkate alınır. Binanın ısı kazançlarının (iç ve güneş), aylık ısıtma yükünü karşılama oranı olarak ifade edilen Aylık Kazanç Kullanım Faktörünün de dikkate alınması gerekmektedir. Aylık kazanç kullanım faktörü, 1sıtma yükünü azaltmak için 1sı kazançlarının sadece bir bölümünün kullanıldığını göstermektedir. Kazanç kullanım faktörü çoğunlukla bina yapım türüne ve bina formuna bağlıdır.

Yukarıdaki bilgilerin ışığında, Şekil 6' da verilen akış diyagramına göre binanın yıllık ısıtma enerjisi ihtiyacı, aylık enerji ihtiyaçlarının toplamıdır ve değer eşitlik (1-6) yardımıyla hesaplanabilir.

Burada,

$\mathrm{Q}_{\mathrm{yl}}$, yıllık 1sıtma enerjisi ihtiyacı (MJ),

$$
\begin{aligned}
& Q_{y 1 l}=\sum_{i=1}^{n} Q_{a y} \\
& Q_{a y}=\left(\mathrm{H} * \Delta \mathrm{T}-\eta_{a y} *\left(\phi_{i c}+\phi_{s}\right)\right) t \\
& \mathrm{H}=H_{T}+H_{V}
\end{aligned}
$$$$
\eta_{a y}=1-e^{\left(-1 / K K O_{a y}\right)}
$$$$
\mathrm{KKO}_{a y}=\left(\phi_{i c ̧}+\phi_{s}\right) /(H * \Delta T)
$$

$\phi_{s}=\sum r_{i, a y} * g_{i, a y} * I_{i, a y} * A_{i}$

$\mathrm{Q}_{\text {ay }}$, aylık 1sıtma enerjisi ihtiyacı (MJ),

$\mathrm{H}$, aylık toplam $1 \mathrm{~s} 1$ kaybı $(\mathrm{W} / \mathrm{K})$,

$\mathrm{H}_{\mathrm{T}}$, iletim ve taşınım yoluyla oluşan $1 \mathrm{~s}$ kaybı (W/K),

$\mathrm{H}_{\mathrm{v}}$, havalandırma yoluyla oluşan ısı kaybı (W/K),

$\Delta \mathrm{T}$, iç ve dış ortamlar arasındaki sıcaklık farkı $\left({ }^{\circ} \mathrm{C}\right)$ 


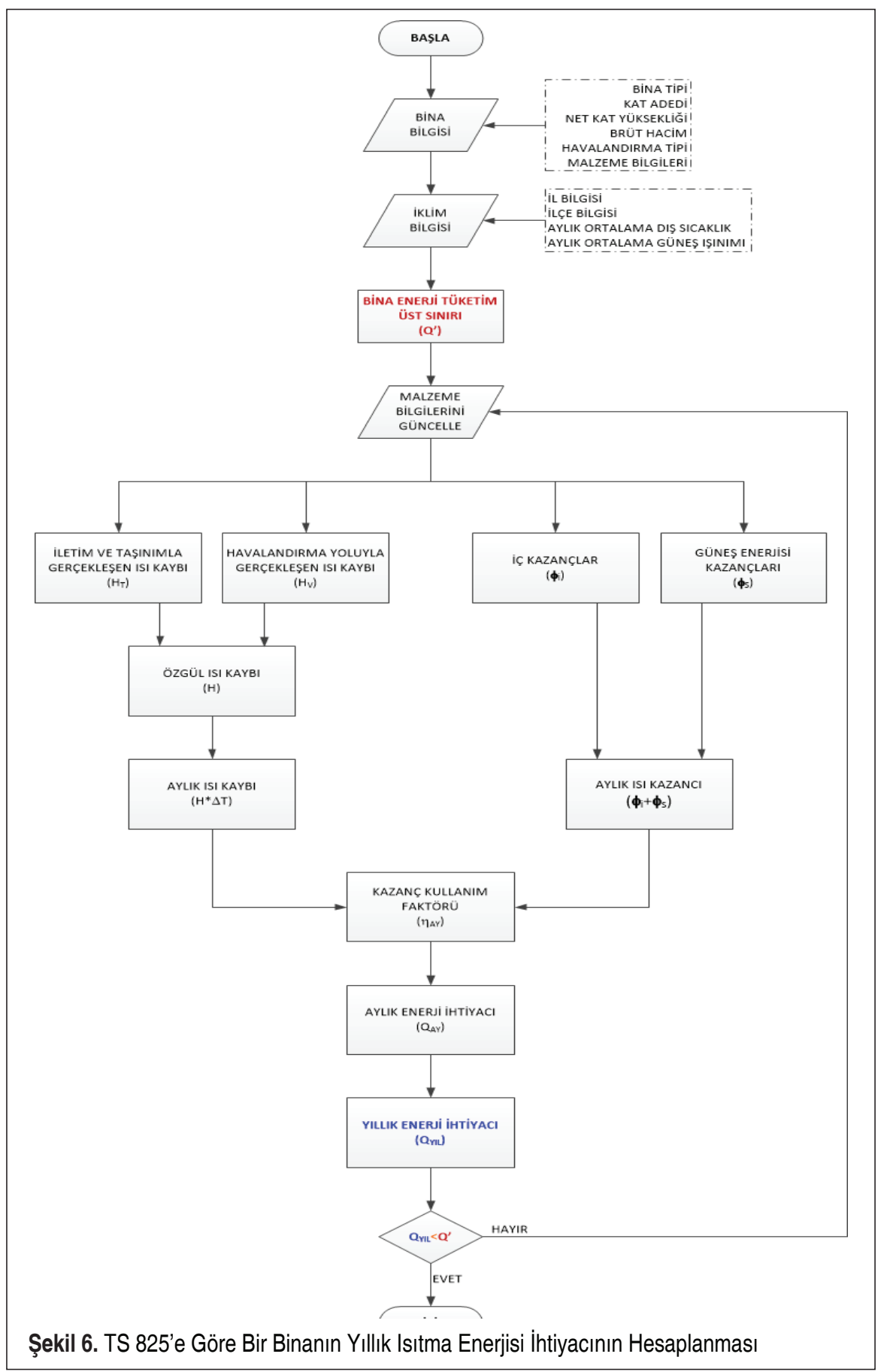


$\phi_{\mathrm{i}}$, aylık iç ısı kazançları $(\mathrm{W})$,

$\phi_{\mathrm{s}}$, aylık güneş enerjisi kazançları $(\mathrm{W})$,

$\eta_{\text {ay }}$, aylık kazanç kullanım faktörü

$\mathrm{KKO}_{\text {ay }}$, kazanç kullanım oranı,

Binanın aylık 1sı kaybı, özgül ısı kaybı ile iç ortam ve dış ortam arasındaki sıcaklık dikkate alınarak hesaplanır. Binanın özgül ısı kaybı ise, iletim ve taşınım yoluyla oluşan ısı kaybı ile havalandırma yoluyla oluşan ısı kaybının toplamıdır. Binanın iç ortam sıcaklığı ise, kararlı hal durumu göre denge noktası sıcaklığı olarak dikkate alınmalıdır.

TS 825 standardında tanımlanan ve Şekil 6'da metodolojisi verilen hesap metoduna göre binanın yıllık ısıtma enerjisi ihtiyacının, binanın içinde bulunduğu iklim bölgesine göre maksimum düzeyde kaybedeceği ısıtma enerjisi ihtiyacı sınır değerin altında olması gerekmektedir. Yıllık 1sıtma enerjisi ihtiyacının sınır değeri, yapının 1sı kaybeden alanlarının toplamı $\left(\mathrm{A}_{\text {top }}\right)$ ile binanın brüt hacminin $\left(\mathrm{V}_{\text {brüt }}\right)$ oranına göre belirlenmektedir. Tespit edilen $A_{\text {top }} / \mathrm{V}_{\text {brüt }}$ oranı ve yapının bulunduğu derece gün bölgesi göz önüne alınarak sınır değerler hesaplanır.

Çalışmada dikkate alınan bina, TS 825'e göre 2.DG (derece-Gün) bölgesinde olup yıllık ısıtma enerjisi ihtiyacı sınır değeri eşitlik (7)'de verildiği gibi hesaplanabilir.

$$
\mathrm{Q}^{\prime}=70 *\left(\frac{A_{\text {top }}}{V_{\text {brüt }}}\right)+24,4
$$

\section{BULGULAR VE TARTIŞMA}

Model binanın 2019 yılı iklim verileri dikkate alınarak Design Builder programı yardımıyla saatlik bazda simülasyonu yapılmıştır. Simülasyon sonucuna göre model binanın yıllık enerji tüketiminin, yük bazında yüzdelik dağılımı Şekil 7'de verilmiştir.

Şekil 7 incelendiğinde model binanın yıllık bazda tükettiği enerji miktarı 263.485 kWh olup, bu tüketim içerisinde kaynak bazında kömürün payı yaklaşık \%89 civarındadır. Bu değerin \%71'i doğrudan 1sı transferi yoluyla oluşan 1sı kaybını karşılamak içindir. Geri kalanı ise, havalandırma ve inflitrasyon yoluyla kaybolan 1sı kaybını dengelemek için harcanan miktardır. Model binanın enerji tüketiminin aylık değişimi Tablo 6'da verilmiştir.

Tablo 6 incelendiğinde, model binada en yüksek tüketimin ocak ayında gerçekleştiği açıkça görülmektedir. Ocak ayında toplam tüketimde 1sıtma için harcanan enerjinin payı yaklaşık \%76,7 kadardır. Isıtma amaçlı tüketilen enerjinin yıllık bazdaki payı ise yaklaşık \%71 değerine erişmektedir. Bu bilgilerden anlaşılacağı üzere Köprübaş1 


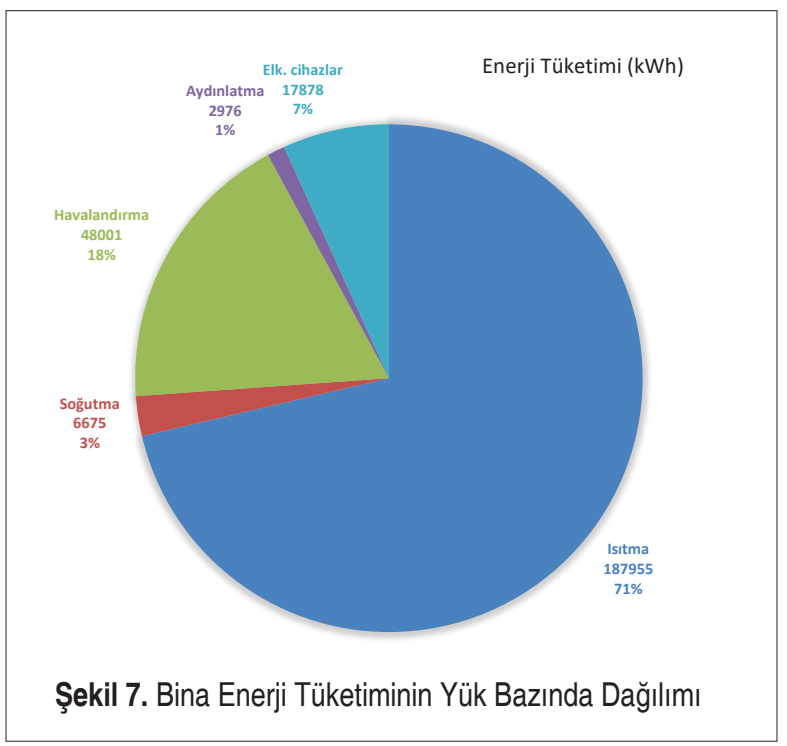

Tablo 6. Enerji Tüketiminin Yük Bazında Aylık Dağılımı

\begin{tabular}{|l|c|c|c|c|c|c|}
\hline \multirow{2}{*}{ Aylar } & Isıtma & Soğutma & Havalandırma & Aydınlatma & Diğer & Toplam \\
\cline { 2 - 7 } & $\mathbf{( k W h )}$ & $\mathbf{( k W h )}$ & $\mathbf{( k W h )}$ & $\mathbf{( k W h )}$ & $\mathbf{( k W h )}$ & $\mathbf{( k W h )}$ \\
\hline Ocak & 50.146 & & 12.806 & 493 & 1.962 & 65.407 \\
\hline Şubat & 41.371 & & 10.566 & 393 & 1.693 & 54.023 \\
\hline Mart & 27.716 & & 7.078 & 357 & 1.558 & 36.710 \\
\hline Nisan & 13.960 & & 3.565 & 273 & 1.331 & 19.129 \\
\hline Mayıs & 463 & & 118 & 162 & 957 & 1.700 \\
\hline Haziran & & 1.002 & & 45 & 2.092 & 3.140 \\
\hline Temmuz & & 1.202 & & 3 & 1.539 & 2.743 \\
\hline Ağustos & & 1.905 & & 7 & 1.132 & 3.044 \\
\hline Eylül & & 1.978 & & 32 & 830 & 2.840 \\
\hline Ekim & & 588 & & 301 & 1.451 & 2.340 \\
\hline Kasım & 9.597 & & 2.451 & 399 & 1.364 & 13.810 \\
\hline Aralık & 44.703 & & 11.416 & 513 & 1.968 & 58.600 \\
\hline Toplam & 187.955 & 6.675 & 48.001 & 2.976 & 17.878 & 263.485 \\
\hline
\end{tabular}

MYO binasının en temel enerji gereksinimi isıtma enerjisi olarak karşımıza çıkmaktadır. Eğer binanın sızdırmazlığı ve enerji etkinlik düzeyi artırılacak olursa, toplamda 1sıtmanın payı oldukça azalacaktır. 
Binanın kullanım alanı başına yük bazlı enerji tüketimi oranları değerlendirilecek olursa, Tablo 7'den de açıkça görüleceği gibi en yüksek enerji yoğunluğu $(66,07$ $\mathrm{kWh} / \mathrm{m}^{2} \mathrm{y}$ ll) 1sıtma enerjisi kullanımındadır.

Köprübaşı MYO binasını enerji açısından iyileştirmek amacıyla model üzerinde birtakım senaryolar oluşturularak değerlendirmelerde bulunulmuştur. Enerji açısından iyileştirme senaryoları 4 farklı duruma göre oluşturulmuştur. Bunlar;

Tablo 7. Model Binanın Enerji Tüketimi ve Enerji Yoğunluğunun Yük Bazında Dağılımı

\begin{tabular}{|l|c|c|c|}
\hline \multirow{2}{*}{ Yükler } & Tüketim & Enerji Yoğunluğu & Dağılım \\
\cline { 2 - 4 } & $\mathbf{( k W h )}$ & $\mathbf{( k W h / \mathbf { m } ^ { 2 } \text { year) }}$ & $\mathbf{( \% )}$ \\
\cline { 2 - 4 } & 187.955 & 66,07 & $\mathbf{7 1 , 3 3}$ \\
\hline Soğutma & 6.675 & 2,35 & 2,53 \\
\hline Havalandırma & 48.001 & 16,87 & 18,22 \\
\hline Aydınlatma & 2.976 & 1,05 & 1,13 \\
\hline Diğer & 17.878 & 6,28 & 6,79 \\
\hline Toplam & 263.485 & 92,61 & 100,00 \\
\hline
\end{tabular}

- Senaryo 1: Opak bileşenlerin yalıtım özellikleri artırılmıştır. Mevcutta model binanın ortalama $1 \mathrm{~s} 1$ geçiş katsayısı $\left(\mathrm{U}_{\text {ort }}\right), 0,89 \mathrm{~W} / \mathrm{m}^{2} \mathrm{~K}$ 'den $0,784 \mathrm{~W} / \mathrm{m}^{2} \mathrm{~K}$ değerine indirgenmiştir. Bunun için model binanın duvarlarında yalıtım kalınlığı $10 \mathrm{~cm}$ olacak şekilde dikkate alınmıştır.

- Senaryo 2: S1'e ek olarak saydan bileşenlerin 1s1 geçiş katsayısı azaltılmıştır. Mevcutta model binanın pencerelerinin $1 \mathrm{~s}$ geçiş katsayısı $\left(\mathrm{U}_{\mathrm{p}}\right), 2,4 \mathrm{~W} / \mathrm{m}^{2} \mathrm{~K}$ yerine $1,2 \mathrm{~W} / \mathrm{m}^{2} \mathrm{~K}$ değeri kabul edilmiştir.

- Senaryo 3: S2'ye ek olarak, güneş kontrolü ve saydamlık oranı azaltılmıştır. Model binanın aydınlatma sistemi gün ışığı otomasyon sistemine bağlanarak tasarım yapılmıştır.

- $\quad$ Senaryo 4: S3’e ek olarak iklimlendirme sistemi değiştirilmiştir.

Oluşturulan senaryolara göre model binanın enerji tüketim değeri yaklaşık \%40 oranında azalarak 263.485 kWh'dan 158.011 kWh'e kadar düşmektedir. Bu değerlendirme sırasında senaryo 1 toplam tüketimi yaklaşık \%11, senaryo $2 \% 26$, senaryo $3 \% 1$ ve senaryo 4 de yaklaşık \%20 kadar iyileştirme sağlamıştır (Tablo 8).

Köprübaşı MYO binası için oluşturulan model binanın simülasyon sonuçlarına göre, her bir senaryo için binanın enerji tüketim yoğunlukları Tablo 9'da verildiği gibidir. Bu tablodan da anlaşılacağı üzere, mevcut durumda model binanın toplam enerji tüketimi açısından enerji yoğunluğu 92,58 kWh/m²yıl iken, yapılan iyileştirmeler sonucunda bu değer $55,52 \mathrm{kWh} / \mathrm{m}^{2} \mathrm{y} 1 \mathrm{l}$ değerine kadar düşmüştür. 
Tablo 8. Model Binanın İyileştirme Senaryolarına Göre Enerji Tüketim Değerleri

\begin{tabular}{|l|c|c|c|c|c|}
\hline \multirow{2}{*}{ Yükler } & Model Bina & $\mathbf{S 1}$ & $\mathbf{S 2}$ & $\mathbf{S 3}$ & S4 \\
\cline { 2 - 6 } & $\mathbf{( k W h )}$ & $\mathbf{( k W h )}$ & $\mathbf{( k W h )}$ & $\mathbf{( k W h )}$ & $\mathbf{( k W h )}$ \\
\hline Isıtma & 187.955 & 165.588 & 137.771 & 137.771 & 95.971 \\
\hline Soğutma & 6.675 & 5.881 & 4.893 & 4.893 & 4.893 \\
\hline Havalandırma & 48.001 & 42.289 & 35.185 & 35.185 & 35.185 \\
\hline Aydınlatma & 2.976 & 2.976 & 2.976 & 2.768 & 2.768 \\
\hline Diğer & 17.878 & 17.878 & 17.878 & 17.878 & 19.194 \\
\hline Toplam & 263.485 & 234.612 & 198.703 & 198.494 & 158.011 \\
\hline
\end{tabular}

Model bina üzerindeki iyileştirme senaryolarına göre binanın ısıtma enerjisi tüketiminin toplam tüketimdeki payı \%10 kadar azalmıştır. Ancak, iyileştirmelerin getirdiği ek tüketimler içerisinde havalandırma ihtiyacı ve mekanik iklimlendirme amaçlı elektrik tüketiminde bir artış gözlemlenmektedir. Mekanik iklimlendirme için tüketilen elektrik enerjisi miktarı, toplam elektrik enerjisi miktarına yaklaşık \% 7'lik bir ek getirmiştir.

Tablo 9. Senaryolara Göre Model Binanın Enerji Yoğunluğu Değişimi

\begin{tabular}{|c|c|c|c|c|c|c|c|}
\hline \multicolumn{2}{|l|}{ Yük } & Isıtma & Soğutma & Havalandırma & Aydınlatma & Diğer & Toplam \\
\hline \multirow{2}{*}{$\begin{array}{l}\text { Model } \\
\text { Bina }\end{array}$} & (kWh/m²yll) & 66,04 & 2,35 & 16,87 & 1,05 & 6,28 & 92,58 \\
\hline & $(\%)$ & 71,33 & 2,53 & 18,22 & 1,13 & 6,79 & 100,00 \\
\hline \multirow{2}{*}{ S1 } & (kWh/m²yıl) & 58,18 & 2,07 & 14,86 & 1,05 & 6,28 & 82,44 \\
\hline & $(\%)$ & 70,58 & 2,51 & 18,03 & 1,27 & 7,62 & 100,00 \\
\hline \multirow{2}{*}{ S2 } & (kWh/m²yıl) & 48,41 & 1,72 & 12,36 & 1,05 & 6,28 & 69,82 \\
\hline & $(\%)$ & 69,34 & 2,46 & 17,71 & 1,50 & 9,00 & 100,00 \\
\hline \multirow{2}{*}{ S3 } & (kWh/m²yıl) & 48,41 & 1,72 & 12,36 & 0,97 & 6,28 & 69,74 \\
\hline & $(\%)$ & 69,41 & 2,46 & 17,73 & 1,39 & 9,01 & 100,00 \\
\hline \multirow{2}{*}{ S4 } & (kWh/m²yıl) & 33,72 & 1,72 & 12,36 & 0,97 & 6,74 & 55,52 \\
\hline & $(\%)$ & 60,74 & 3,10 & 22,27 & 1,75 & 12,15 & 100,00 \\
\hline
\end{tabular}

Köprübaşı MYO binasının simülasyonu için dikkate alınan model bina ve simülasyon kriterlerinin ne derece etkin bir sonuç doğurduğu aslında, mevcut binanın gerçek tüketimleri dikkate alınarak yorumlanması gereken bir durumdur. Bu yüzden, mevcut binanın ölçülen enerji tüketimlerinin yüklere göre dağılımının oluşturulması gerekmektedir.

Proje kapsamında kurulan enerji ölçüm sistemi sayesinde, klimaların ve binadaki prizlerden tüketilen elektrik enerjisinin tüketimi yıl boyunca saatlik bazda ölçülmüş- 
tür. Aşağıdaki bölümde bu ölçüm değerlerine göre oluşturulan hesaplamalarda aydınlatma için öngörülen tüketim değeri bir model oluşturularak tahminlenmeye çalışılmiştır.

Ayrıca binanın 1sıtılması için kullanılan kömür miktarları aylık düzeyde kg bazında bilindiği için hesaplamalarda aylık olarak dikkate alınmıştır.

Proje kapsamında değerlendirmesi gerçekleştirilen Köprübaşı MYO binasının hem gerçek enerji tüketim değerleri hem de Design Builder programında oluşturulan model binanın 2019 yılında ait Köprübaşı iklim koşulları altındaki simülasyon sonuçları daha önceki bölümlerde detaylı olarak verilmiştir.

Elde edilen simülasyon ve ölçüm sonuçlarına göre binanın toplam enerji tüketimindeki farklılığından kaynaklanan hata oranı yaklaşık \%2,45 olarak hesaplanmıştır. Yük bazında kıyaslama yapıldığı zaman, oldukça yüksek farklılıklar görülmektedir. Bunun nedeni, simülasyon için seçilen kriterlerin ve kabullerin farklılıklar içermesidir.

Ancak yük bazlı enerji tüketiminden kaynaklanan hata oranlarının aslında toplam tüketim içerisindeki payının az olmasından dolayı çok da büyük önem kazanmamaktadır. Tüm enerji simülasyonları toplam tüketimi dikkate alarak sonuç ürettiği için hesaplanan hata oranı kabul edilebilir durumdadır (Tablo 10).

Köprübaşı MYO binasının enerji tüketimi açısından genel bir değerlendirme yapacak olursak, ölçüm sonuçlarına göre binanın yıllık toplamdaki tükettiği enerji 257.185 kWh olup, aynı değer simülasyonu gerçekleştirilen model bina için $263.485 \mathrm{kWh}$ olarak gerçekleşmiştir. Model bina üzerindeki iyileştirmeler dikkate alındığında bu değer 158.011 kWh değerine kadar inmiştir (Şekil 8).

Ölçüm sonuçları ile model sonuçları arasındaki hata payı da dikkate alınarak mevcut

Tablo 10. Ölçülen Değerler ile Model Binanın Karşılaştırması

\begin{tabular}{|l|c|c|c|}
\hline \multirow{2}{*}{ Yük } & Ölçülen & Model & Hata \\
\cline { 2 - 4 } & $\mathbf{( k W h )}$ & $\mathbf{( k W h )}$ & $\mathbf{( \% )}$ \\
\hline Isıtma & 177.384 & 187.955 & $-5,96$ \\
\hline Soğutma & 4.248 & 6.675 & $-57,15$ \\
\hline Havalandırma & 54.218 & 48.001 & 11,47 \\
\hline Aydınlatma & 2.670 & 2.976 & $-11,48$ \\
\hline Diğer & 18.667 & 17.878 & 4,23 \\
\hline Toplam & 257.185 & 263.485 & $-2,45$ \\
\hline
\end{tabular}




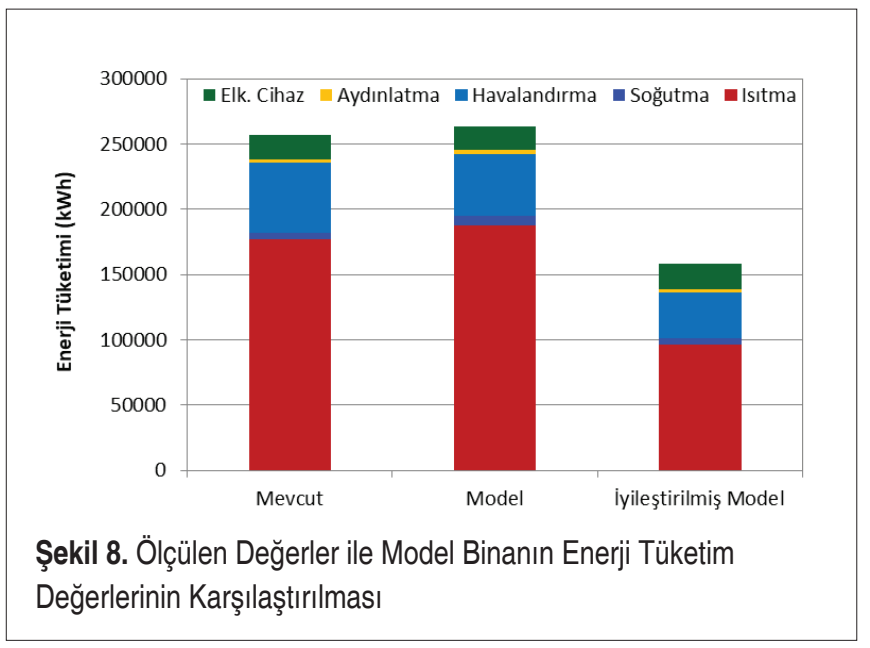

binanın iyileştirmeler sonucunda tüketeceği enerji miktarı $154.233 \mathrm{kWh}$ olarak hesaplanabilir. $\mathrm{Bu}$ değer mevcut binanın iyileştirilmiş durumu ile arasında \%40 civarında bir enerji tasarrufu olacağını göstermektedir.

Mevcut binanın ölçülen gerçek tüketim verileri ile model binanın yük bazlı enerji tüketim radarı Şekil 9 a'da ve iyileştirmeler sonucundaki radar grafiği de Şekil 9 b'de verilmiştir.

Köprübaşı MYO binasında 2019 yılı boyunca gerçekleştirilen ölçüm sonuçlarına göre binanın toplam enerji tüketimine göre enerji yoğunluğu, kullanım alanı başına yaklaşı $62,35 \mathrm{kWh} / \mathrm{m}^{2} \mathrm{y} ı 1$ iken, model binanın aynı iklim koşulları altında enerji yoğunluğu $66,05 \mathrm{kWh} / \mathrm{m}^{2} \mathrm{y}$ ll olarak hesaplanmıştır (10).

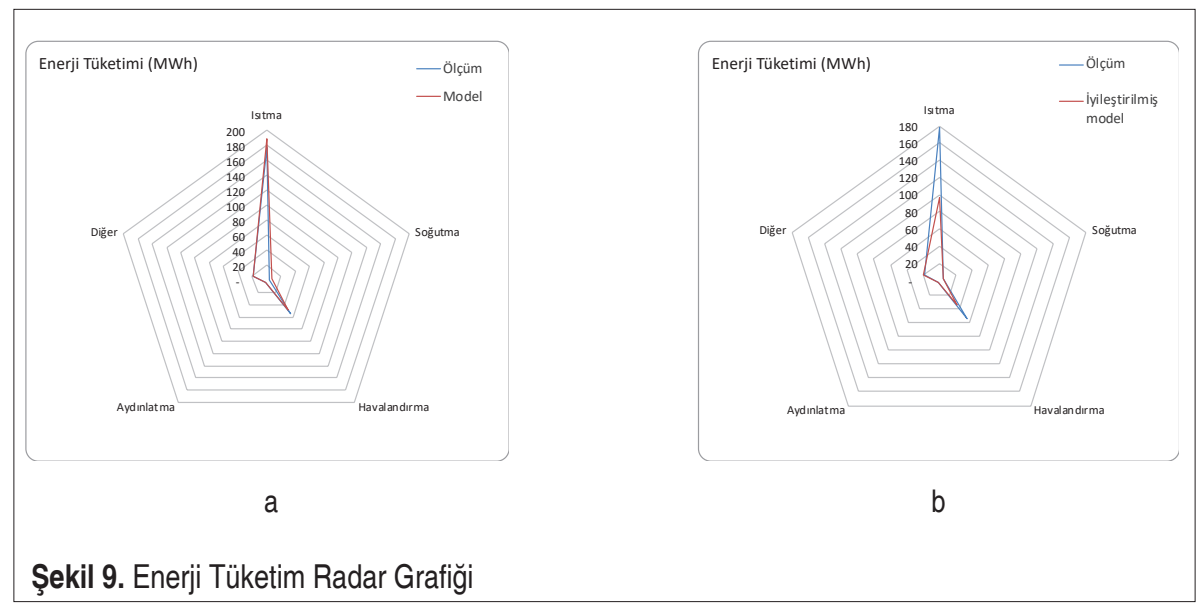




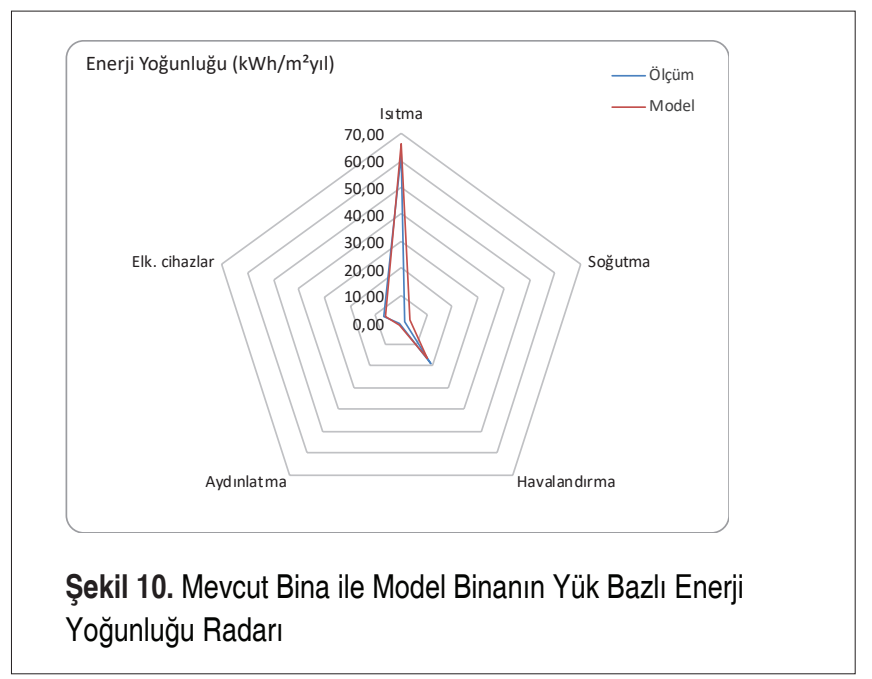

\section{SONUÇLAR}

Köprübaşı MYO binasının enerji performansı iklimlendirme açısından rahatlıkla iyileştirilebilir bir durum sergilemektedir. Özellikle binanın çatısında kurulu olan Fotovoltaik Güneş Enerjisi Santralinin kapasitesi dikkate alındığı zaman, hava kaynaklı bir ısı pompası ile binanın iklimlendirilmesi oldukça yararlı olacaktır. Aynı zamanda 1sıtma için kullanılan kömürün yarattığı sera gazı emisyonunda da yüksek oranda azalma sağlanacaktır. Eğer simülasyon için önerilen senaryolar gerçekte uygulamaya sokulacak olursa, Binanın enerji yoğunluğu $90,4 \mathrm{kWh} / \mathrm{m}^{2} \mathrm{y}$ ll' dan yaklaşık 55,54 kWh/ $\mathrm{m}^{2} \mathrm{y}$ l değerine ulaşacaktır ki, bu binayı enerji verimliliği açısından bir üst sınıfa taşıyacaktır.

Seragazı emisyonu açısından oldukça yüksek salıma sahip olan binada, kullanım alanı başına yıllık toplamda $74,90 \mathrm{~kg}-\mathrm{CO}_{2} / \mathrm{m}^{2} \mathrm{y}$ 1l değerinde iken, önerilen iyileştirmeler ve çatıdaki FV-GES'in desteğiyle bu değer $12,61 \mathrm{~kg}-\mathrm{CO}_{2} / \mathrm{m}^{2} \mathrm{y}$ l değerine kadar düşecektir. Bu sonuç binayı oldukça yüksek oranda çevre duyarlı bir duruma getirecektir.

Proje kapsamında dikkate alınan Köprübaşı MYO binasının enerji tüketiminde ciddi oranda tasarruf potansiyeline sahip olduğu, ayrıca yenilenebilir enerji kullanımı ile binanın enerji tüketimleri, enerji maliyetleri ve $\mathrm{CO}_{2}$ emisyon miktarlarının yüksek oranlarda azaltılabildiği tespit edilmiştir.

\section{TEŞEKKÜR}

Bu çalışma Manisa Celal Bayar Üniversitesi Bilimsel Araştırma Projeleri Koordinasyon Birimi tarafından desteklenmiştir (Proje Numarası: BAP 2018-062). Ayrıca bu 
çalışmada adı geçen 30kW çatı üstü FV GES, Zafer Kalkınma Ajansı tarafından \%75 oranında hibe ile desteklenmiştir. (Proje Numarası: TR33-16-SUCEP-0028).

\section{KAYNAKÇA}

1. Öztürk, H., K. 2020. “Rüzgar Türbinlerinde İşletme ve Bakım”, Mühendis ve Makina, Vol 61, Say1 701, pp. 262-279

2. Dawar, A., Kaya, M., F. 2021. "Güneş Enerjisi Depolama Malzemelerinin Bugünü, Yarını ve Geleceği”, Mühendis ve Makina, Vol 62, Say1 702, pp. 70-90

3. Kılkış, B. 2020. "Yapılardaki Kat Adedinin Büyük Kentlerin Güneş Enerjisinden Akılcı Yararlanmasına Etkileri”, Mühendis ve Makina, Vol 61, Sayı 699, pp. 81-115

4. ExxonMobil. 2019. "2019 Summary Annual Report. Texas, USA”, pp. 1-58 (https:// corporate.exxonmobil.com/-/media/Global/Files/investor-relations/annual-meetingmaterials/annual-report-summaries/2019-Summary-Annual-Report.pdf, Erişim tarihi: 10.04.2019).

5. TBMM. 2007. "5627 Sayılı Enerji Verimliliği Kanunu”, Türkiye Cumhuriyeti Resmi Gazete, No 26510.

6. TBMM. 2008. "Binalarda Enerji Performans Yönetmeliği”, Türkiye Cumhuriyeti Resmi Gazete, No 27075.

7. Altan, H., S Douglas, J., Kim, Y. K. 2014. "Energy Performance Analysis of University Buildings: Case Studies at Sheffield University, UK", Journal of Architectural Engineering Technology, Vol 3, Issue 3, pp.1-13.

8. Altan, H. 2010. "Energy efficiency interventions in UK higher education institutions", Energy Policy, Vol 38, Issue 12, pp. 7722-7731.

9. Salleh, M. N. M., Kandar, M. Z., Sakip, S. R. M. 2016. "Benchmarking for Energy Efficiency on School Buildings Design: A Review”, Procedia - Social and Behavioral Science. Vol 222, pp.211-218.

10. Abdallah, A. S. H. 2015. "Analysis of Thermal Comfort and Energy Consumption in Long Time Large Educational Halls (Studios), Assiut University, Egypt”, Procedia Engineering, Vol 121, pp.1674-1681.

11. Bourdeau, M., Guo, X., Nefzaoui, E. 2018. "Buildings energy consumption generation gap: A post-occupancy assessment in a case study of three higher education buildings", Energy and Buildings, Vol 159, pp. 600-611.

12. Dixit, M. K., Singh, S. 2018. "Embodied energy analysis of higher education buildings using an input-output-based hybrid method" Energy and Buildings, Vol 161, pp.41-54.

13. Yousefi, Y., Yousefi, S., Yousefi, Y. 2015. "Energy-efficiency in educational buildings in iran : analysis and measures School of Construction and the Environment”, Building Simulation Conference, Ilam University, Iran, pp. 169-174.

14. Lawrence, R., Keime, C. 2016. "Bridging the gap between energy and comfort: Post- 
occupancy evaluation of two higher-education buildings in Sheffield", Energy and Buildings, Vol 130, pp. 651-666.

15. Ostojić, S., Veršić, Z., Muraj, I. 2016. "Energy analysis and refurbishment strategy for Zagreb University buildings: Former Faculty of Technology in Zagreb by Alfred Albini”, Energy and Buildings, Vol 115, pp. 47-54.

16. Guan, J., Nord, N., Chen, S. 2016. "Energy planning of university campus building complex: Energy usage and coincidental analysis of individual buildings with a case study", Energy and Buildings, Vol 124, pp. 99-111.

17. Hawkins, D., Mumovic, D. 2017. "Evaluation of life cycle carbon impacts for higher education building redevelopment: a multiple case study approach", Energy and Buildings, Vol 150, pp. 507-515.

18. Hawkins, D., Mumovic, D. 2017. "Evaluation of life cycle carbon impacts for higher education building redevelopment: an archetype approach", Energy and Buildings, Vol 147 , pp. 113-122.

19. Wang, C., Kilkis, S., Tjernström, J., Nyblom, J., Martinac, I. 2017. "Multi-objective Optimization and Parametric Analysis of Energy System Designs for the Albano University Campus in Stockholm", Procedia Engineering, Vol 180, pp. 621-630.

20. Li, L., Tong, Z., Linhua, Z., Hongchang, S. 2017. "Energy Consumption Investigation and Data Analysis for one university of Guangzhou", Procedia Engineering, Vol 205, pp. $2118-2125$.

21. Khoshbakht, M., Gou, Z., Dupre, K. 2018. "Energy use characteristics and benchmarking for higher education buildings", Energy and Buildings, Vol 164, pp. 61-76.

22. Kim, A. A., Sunitiyoso, Y., Medal, L. A. 2019. "Understanding facility management decision making for energy efficiency efforts for buildings at a higher education institution" Energy and Buildings, Vol 199, pp. 197-215.

23. Leal Filho, W., Salvia, A. L., Paço, A. do, Anholon, R., Gonçalves Quelhas, O. L., Rampasso, I. S., Ng. A., Balogun. A. L., Kondev, B., Brandli, L. L. 2019. “A comparative study of approaches towards energy efficiency and renewable energy use at higher education institutions", Journal of Cleaner Production, Vol 237, pp. 1-23.

24. Wang, J. C. 2019. "Analysis of energy use intensity and greenhouse gas emissions for universities in Taiwan”, Journal of Cleaner Production, Vol 241, pp. 1-15.

25. Ocampo Batlle, E. A., Escobar Palacio, J. C., Silva Lora, E. E., Martínez Reyes, A. M., Melian Moreno, M., Morejón, M. B. 2020. "A methodology to estimate baseline energy use and quantify savings in electrical energy consumption in higher education institution buildings: Case study", Federal University of Itajubá (UNIFEI). Journal of Cleaner Production, Vol 244, pp. 1-18.

26. Ariyo, B. O., Akorede, M. F., Omeiza, I. O. A., Amuda, S. A. Y., Oladeji, S. A. 2018. "Optimisation analysis of a stand-alone hybrid energy system for the senate building, University of Ilorin, Nigeria”, Journal of Building Engineering, Vol 19, pp. 285-294. 
27. Saydam, D, B., Özalp, C., Hürdoğan, E., Polat, C., Kavun, E. 2021. "Yeşil Çatı Uygulamasının Örnek Bir Bina İçin Isıtma İhtiyacı ve Çevre Emisyonlarına Etkisinin İncelenmesi”, Mühendis ve Makina, Vol 62, Say1 703, pp. 204-220

28. Koyun, T., Koç, E. 2017. "Bir Binanın Değişken Cam ve Dış Duvar Tiplerine Göre Pencere/Duvar Alanı Oranlarının Bina Isı Kayıplarına Etkisi”, Mühendis ve Makina, Vol 58, Say1 688 , pp. $1-14$

29. Yücer, C. 2016. "Ekserji analizi yöntemi kullanılarak bina 1sıtma sistemlerinin incelenmesi”, Mühendis ve Makina, Vol 57, Say1 681, pp. 59-64.

30. Bayar, U., Atılgan, A. 2015. "Yeşil ev tasarımı ve enerji analizi için uygulama örneği”", Mühendis ve Makina, Vol 56, Say1 671, pp. 41-52

31. Haydaraslan, E., Çuhadaroğlu, B., Yaşar, Y. 2020. "Kat Isıtmasında Yüzer Döşeme ve Faz Değiştiren Malzeme Kullanımının Enerji Verimliliğine ve Konfor Koşullarına Etkisi”, Mühendis ve Makina, Vol 61, Say1 700, pp. 180-197

32. Tokuç, A. 2009. "Bina enerji benzetim araçları ve seçim ölçütleri”, Dokuz Eylül Üniversitesi Mühendislik Fakültesi Fen ve Mühendislik Dergisi, Vol 11, Say1 2, pp. 19-30.

33. Kılıçlı, A. 2018. "Ege Üniversitesi Bünyesindeki Mevcut Bir Binanın Enerji-Ekserji Analizi ve İyileştirme Önerileri”, Yayınlanmamış Doktora Tezi, Fen Bilimleri Enstitüsü Ege Üniversitesi, pp. 1-146.

34. Akdemir M. 2013. "Dynamic energy and exergy analysis of an existing Building in Iztech”, Yayınlanmamış Yüksek Lisans Tezi, Fen Bilimleri Enstitüsü IYYTE, pp. 1-111.

35. Rüşen, S., Topçu, M., Karanfil Celep, G., Çeltek, S., Rüsşen, A. 2013. "Üniversite kampüs binaları için enerji etüdü: örnek çalışma”, Çukurova Üniversitesi MühendislikMimarlık Fakültesi Dergisi, Vol 33, Sayı 2, pp. 83-92.

36. Ateş, A., M., Ülgen, K. 2018. "Eğitim binalarının enerji verimliliği performansının değerlendirmesi: Köprübaşı MYO Örneği”, Bilimsel Araştırma Projesi, MCBÜ, Proje No:2018-062, pp. 1-78.

37. İZODER. 2019. “TS 825 Hesap Yöntemi”, İZODER Is1 Su Ses ve Yangın Yalıtımc1ları Derneği, (https://www.izoder.org.tr/hesap-makinesi/ts_825_yardim.pdf, Erişim tarihi: 19.04.2020). 